\title{
Assessing influenza-related mortality: Comment on Zucs et al. Jonathan Dushoff*1,2
}

\author{
Address: ${ }^{1}$ Princeton U. Dept. of Ecology and Evolutionary Biology, Princeton NJ, 08544, USA, ${ }^{2}$ National Institutes of Health, Fogarty International \\ Center, Bethesda MD, 20892, USA \\ Email: Jonathan Dushoff* - dushoff@eno.princeton.edu \\ * Corresponding author
}

Published: 21 July 2005

Emerging Themes in Epidemiology 2005, 2:7 doi:10.1 186/1742-7622-2-7

This article is available from: http://www.ete-online.com/content/2/I/7

(C) 2005 Dushoff; licensee BioMed Central Ltd.

This is an Open Access article distributed under the terms of the Creative Commons Attribution License (http://creativecommons.org/licenses/by/2.0), which permits unrestricted use, distribution, and reproduction in any medium, provided the original work is properly cited.

Influenza is an important source of mortality and morbidity, and an important public health priority. Measuring the health burden imposed by influenza viruses is an important, and still controversial, question. Some authors argue that influenza is directly or indirectly responsible for the majority of seasonal excess deaths in temperate countries [1], while others argue that they trigger only a small minority [2]. Retrospective cohort studies have shown a surprisingly large protective effect of influenza vaccination against deaths from any cause [3-5], and one author has provocatively suggested that increased influenza vaccination of the elderly could halve the total mortality rate [6]. The population-level interpretation of these cohort studies is not clear, however [7], and studies in the Netherlands [8] and Britain [9] have found substantially lower protection. The present contribution [10] is a welcome addition to the data base that can be used to address this important question. But much more remains to be done to standardize and improve methods, and to reconcile the results obtained from different approaches.

The impact of influenza is difficult to measure, because there is a great deal of influenza-like illness (ILI) in the world, caused by a large number of viruses, and only a very small percentage of cases is confirmed virologically [11]. Deaths triggered by influenza may be attributed to a number of final causes, including pneumonia, heart disease and stroke, and may occur weeks after initial infection $[1,12,13]$.

The work of [10] is based on a long tradition of estimating influenza deaths by inference from seasonal patterns in death series. This method was pioneered by Serfling [14], and further developed by workers including Simonsen
Received: 23 June 2005

Accepted: 21 July 2005 and colleagues $[7,15]$. While this work is valuable, and has produced apparently robust results, it is largely disconnected from quantitative virologic data about influenza. Thus, attribution of health effects to influenza is based strongly on assumptions about underlying death trends.

Recently, Thompson and colleagues have used virologic surveillance data to estimate influenza mortality [13] and hospitalizations [16], using a weekly, seasonal regression model. These models are the first to link quantitative virologic information to measures of influenza burden at the population level. The estimates produced are consistent with those of Serfling-like estimates $[7,17]$ and are robust to the addition of estimates of respiratory syncytial virus (RSV) prevalence to the regressions. Questions remain about these estimates, however. The work of Thompson and colleagues removes a sinusoidal trend (fit at the same time as influenza prevalence), but does not take into account issues of autocorrelations; or the possibility of seasonal confounding between influenza prevalence, morbidity and mortality, and such factors as day length, temperature or school terms; or the likelihood that deaths caused by influenza infection in a given week may not occur until several weeks later.

Keatinge, Donaldson and colleagues [2,18], also used simple regression methods that ignored autocorrelations and seasonal confounding to study the causes of winter mortality in Europe. Unlike Thompson and colleagues, they lacked virological data and instead used proxies for influenza, but included temperature data, and found that temperature rather than influenza explained most of the excess deaths in their models. 
Approaching a consensus on the health and mortality burden of influenza, and on the cause of winter excess mortality in general, is an important scientific and publicpolicy goal. For this to happen, further progess is needed in several areas.

- Employing virological data. When possible, analyses of influenza burden should be tied to estimates of laboratory-confirmed influenza cases. In some cases, such measures can be combined with ILI surveillance to improve estimates. Efforts should be made to increase the amount of viral surveillance information available in the public domain, with spatial and temporal break downs.

- More sophisticated statistical analyses. Time series methods that address issues of seasonal confounding and autocorrelation are available $[19,20]$, but have been little used in analyses of seasonal mortality. Helfenstein [21] analyzed paired pre-whitened mortality series and inferred a "hidden relation" underlying heart disease in women and men. Much more needs to be done to investigate the relationship between mortality (or morbidity) and co-factors including weather, air pollution and epidemics of influenza and other viruses, while accounting for seasonal confounding and autocorrelations. Methods should evaluate multiple risk factors and consider the possibility of interactions between them.

- Discuss and define time scales. An important, and usually unasked, question in comparing results from different estimation approaches is the time scale on which influenza deaths are being measured. Everybody dies, so what is being measured as the mortality burden of influenza (or of weather) is deaths that are hastened by the cause in question. The question is whether these deaths are being hastened by weeks, months or years. Regressions that use a weekly time frame are expected to count deaths hastened by even a few weeks, while traditional methods of summing excess deaths over a season of 3 months or longer will be measuring at a different time scale.

- Quantitative spatial comparisons. As regional surveillance data, and data from different countries, become more available, analyses that explicitly incorporate risk factors and health outcome variables from various localities have the potential to greatly increase statistical power and shed light on unravelling the contribution of influenza and other risk factors to mortality and morbidity.

The contribution of influenza to morbidity and mortality - and, more broadly, cataloging the causes of daily and seasonal excess deaths and hospitalizations - remain as unresolved questions with important scientific and public-health implications. There is a pressing need for more communication between researchers studying different causes, places and time scales, and for application of appropriate, powerful statistical methods to these questions.

\section{Competing interests}

The author(s) declare that they have no competing interests.

\section{References}

I. Reichert TA, Simonsen L, Sharma A, Pardo SA, Fedson DS, Miller MA: Influenza and the winter increase in mortality in the United States, 1959-1999. Am J Epidemiol 2004, I 60:492-502.

2. Donaldson GC, Keatinge WR: Excess winter mortality: influenza or cold stress? Observational study. B M J 2002, 324:89-90.

3. Nichol KL, Goodman M: The health and economic benefits of influenza vaccination for healthy and at-risk persons aged 65 to 74 years. Pharmacoeconomics 1999, 16:63-71.

4. Hak E, Nordin J, Wei FF, Mullooly J, Poblete S, Strikas R, Nichol KL: Influence of high-risk medical conditions on the effectiveness of influenza vaccination among elderly members of 3 large managed-care organizations. Clin Infect Dis 2002, 35:370-377.

5. Nichol KL, Nordin J, Mullooly J, Lask R, Fillbrandt K, Iwane M: Influenza vaccination and reduction in hospitalizations for cardiac disease and stroke among the elderly. N Engl J Med 2003, 348: $1322-1332$.

6. Poland GA: If you could halve the mortality rate, would you do it? Clin Infect Dis 2002, 35:378-380.

7. Simonsen L, Reichert TA, Viboud C, Blackwelder WC, Taylor RJ, Miller MA: Impact of Influenza Vaccination on Seasonal Mortality in the US Elderly Population. Arch Intern Med 2005, 1 65:265-72.

8. Voordouw ACG, Sturkenboom MCJM, Dieleman JP, Stijnen T, Smith DJ, van der Lei J, Stricker BHC: Annual revaccination against influenza and mortality risk in community-dwelling elderly parsons. JAMA 2004, 292:2089-2095.

9. Mangtani P, Cumberland P, Hodgson CR, Roberts JA, Cutts FT, Hall AJ: A cohort study of the effectiveness of influenza vaccine in older people, performed using the United Kingdom General Practice Research Database. J Infect Dis 2004, 190:1-10.

10. Phillip Zucs, Udo Buchholz, Walter Haas, Helmut Uphoff: Influenza associated excess mortality in Germany, 1985-2001. Emerg Themes Epidemiol, 2005, 2:6

II. Cox NJ, Subbarao K: Influenza. Lancet I999, 354:| 277-I 282.

12. Glezen WP, Payne AA, Snyder DN, Downs TD: Mortality and influenza. I Infect Dis 1982, 146:313-321.

13. Thompson WW, Shay DK, Weintraub E, Brammer L, Cox N, Anderson LJ, Fukuda K: Mortality associated with influenza and respiratory syncytial virus in the United States. JAMA 2003, 289: | 79- I86.

14. Serfling RE: Methods for current statistical analysis of excess pneumonia influenza deaths. Public Health Rep 1963, 78:494-506.

15. Simonsen L, Clarke MJ, Williamson GD, Stroup DF, Arden NH, Schonberger LB: The impact of influenza epidemics on mortality: Introducing a severity index. Am J Public Health 1997, 87:1944-1950.

16. Thompson WW, Shay DK, Weintraub E, Brammer I, Bridges CB, Cox NJ, Fukuda K: Influenza-associated hospitalizations in the United States. JAMA 2004, 292: I333-I340.

17. Simonsen L, Blackwelder WC, Reichert TA, Miller MA: Letter: Estimating deaths due to influenza and respiratory syncytial virus. JAMA 2003, 289:2499-2500.

18. Keatinge WR, Donaldson GC, Bucher K, Jendritsky G, Cordioli E, Martinelli M, Dardanoni L, Katsouyanni K, Kunst AE, Mackenbach JP, McDonald C, Nayha S, Vuori I: Cold exposure and winter mortality from ischaemic heart disease, cerebrovascular disease, respiratory disease, and all causes in warm and cold regions of Europe. Lancet 1997, 349:134|-1346.

19. Haugh LD, Box GEP: Identification of dynamic regression (distributed lag) models connecting 2 time series. J Am Stat Assoc 1977, 72:12I-130.

20. Diggle PJ: Time Series: A Biostatistical Introduction Oxford University Press, Oxford; 1990. 
21. Helfenstein U: Detecting hidden relations between time series of mortality rates. Methods $\ln$ Med 1990, 29:57-60.

Publish with Bio Med Central and every scientist can read your work free of charge

"BioMed Central will be the most significant development for disseminating the results of biomedical research in our lifetime. " Sir Paul Nurse, Cancer Research UK

Your research papers will be:

- available free of charge to the entire biomedical community

- peer reviewed and published immediately upon acceptance

- cited in PubMed and archived on PubMed Central

- yours - you keep the copyright

Submit your manuscript here:

http://www.biomedcentral.com/info/publishing_adv.asp 